\title{
The incubation period of beet yellowing viruses in sugar-beet under field conditions
}

\author{
W. VAN DER WERF ${ }^{1,2}$, C. KEMPENAAR' and D. PETERS ${ }^{\prime}$ \\ 1 Department of Virology, Wageningen Agricultural University, P.O. Box 8045, 6700 EM Wage- \\ ningen, the Netherlands \\ 2 Department of Theoretical Production Ecology, Wageningen Agricultural University, P.O. Box \\ 430, 6700 AK Wageningen, the Netherlands
}

Accepted 6 July 1989

\begin{abstract}
In three years field trials, the incubation period, i.c. the time between infection and the appearance of symptoms, of beet yellows virus (BYV) and beet mild yellowing virus (BMYV) increased with later infection during the growing season. The incubation period of BY V, a closterovirus, increased from 3 weeks in young plants infected before canopy closure, to 9 weeks in old plants infected in August. The incubation period of BMYV, a luteovirus, increased from 4 to 5 weeks in young plants to 9 weeks in old plants. Symptoms were observed c. one week earlier on the inoculated leaves than on those infected systemically, except on young BY V-infected plants. On these plants, symptoms developed in 3 weeks on both leaf types.

The incubation period decreased at increasing temperature, a fixed temperature sum being required for the development of symptoms on plants of a certain age. This temperature sum increased with plant age. Symptom development was related to leaf growth; the systemic symptoms appeared after the infected leaves attained their final size. Young, expanding leaves did not show symptoms. Thus the development of symptoms seems to be related to physiological conditions occurring only in full-grown leaves. A low rate of leaf expansion may constitute the underlying reason for the long incubation period of virus symptoms in old plants and at low temperatures.

The incubation period was not substantially affected by: (1) the number of Myzus persicae used to inoculate the plants, (2) the number of leaves inoculated, (3) the development stage of the inoculated leaf and (4) the source plant of BMYV, beet or shepherd's-purse, Capsella bursapastoris. The incubation period can be used to obtain rough estimates of the infection-date of individual plants, given the date on which symptoms appear.
\end{abstract}

Additional keywords: beet yellows virus, closterovirus, beet mild yellowing virus, luteovirus, Myzus persicae, local symptoms, systemic symptoms, plant age, temperature sum, leaf growth, estimation of date of infection

\section{Introduction}

Virus yellows is an economically important disease of sugar-beet, Beta vulgaris ssp. saccharifera. Studies in Europe (Russell, 1958, 1963, 1965b; Björling and Möllerström, 1974; Thielemann and Nagi, 1977; Häni, 1979; Smith, 1986; Smith and Hinckes, 1987) have shown that the disease is most often caused by beet mild yellowing virus (BMYV, luteovirus group). Beet yellows virus (BYV, closterovirus group) is less important (Duffus, 1973; Bar-Joseph et al., 1979). Upon infection with BYV or BMYV beet leaves become 
thick and brittle, while their starch and sugar content increases (Watson and Watson, 1951). The photosynthetic capacity of the plant decreases (Hall and Loomis, 1972a,b). Symptoms develop on the inoculated leaves, on which aphids infected the beet plant, and on systemically-infected leaves, to which virus has been transported via the phloem system. Systemic infection extends to a few young leaves present in the heart of the plant on the infection-date and to all leaves that appear later (Roseboom and Peters, 1984; Van der Werf et al., 1989a). Symptoms of BMYV develop with leaf age from paleyellow to bright-yellow or orange, culminating in necrosis as a result of infection by Alternaria spp. (Russell, 1964a,b). BYV causes vein clearing in the first leaves expanding after infection. Systemically-infected leaves become yellow when they mature and develop typical red or necrotic spots subsequently.

The green peach aphid, Myzus persicae, is the major vector of beet yellowing viruses in the field (Watson et al., 1951; Björling, 1952; Heathcote, 1966). The black bean aphid, Aphis fabae, is a second, much less important vector of BYV. This aphid species does not transmit BMYV (Russell, 1963; Björling and Nilsson, 1966); however, Thielemann and Nagi (1979) and Karl and Giersemehl (1981) came to a different conclusion. The population dynamics of $M$. persicae and the concomitant spread of beet yellowing viruses have been studied by many authors (a.o. Björling et al., 1951; Björling, 1952; Watson and Healy, 1953; Ribbands, 1963; Kershaw, 1965; Watson and Heathcote, 1966). Though these studies have learnt a lot about the epidemiology of beet yellowing viruses, they do not shed much light on the relationship between aphid vector population dynamics in time and space and the concomitant spread of virus, which becomes manifest after the incubation period (the time period between infection and the appearance of symptoms; Van der Plank, 1963; Bos et al., 1985). Therefore, the incubation period of the disease must be known. However, no systematic observations on the incubation period of BYV and BMYV under field conditions have been made.

Reports in the literature indicate that the incubation period of beet yellowing viruses varies widely according to inoculation-date (Wiesner, 1959; Thiclemann and Nagi, 1977), weather (Wiesner, 1959), year (Thielemann and Nagi, 1977), vector species (Thielemann and Nagi, 1977) and number of vectors (Steudel, 1958). The work presented here has two aims: (1) to identify the factors which have a great influence on the incubation period, and (2) to provide estimates of the incubation period for analyses of experiments on virus spread (Van der Werf et al., in prep.).

\section{Materials and methods}

Arrangement of experiments. The effect of five factors on the incubation period was studied: (1) infection-date: May to August, (2) number of vector aphids, $M$. persicae: 1 to 30,10 as a standard, (3) number of inoculated leaves: 1 (standard) to 4, (4) development stage of inoculated leaf: expanding, just full-grown (standard) or ageing, (5) sowing date: mid-April (standard), end of May or early-July.

In a few plots, inoculations with BYV were made using $A$. fabae to study a possible effect on the incubation period. Additionally, in 1986, inoculations were made with M. persicae which had acquired BMYV from shepherd's-purse, Capsella bursa-pastoris, instead of beet. Further details are given below.

Experiment I. Sugar-beets 'Regina' were sown on 24 April 1985 on a riverclay soil 
at the Binnenhaven in Wageningen. Each combination of the experimental factors 1 to 4 was applied to two duplicate rows of 15 plants. To inoculate a plant $10,5,2$ or $1 \mathrm{M}$. persicae were used (factor 2 ). One or three leaves were inoculated (factor 3 ). Twelve plots of $2.5 \times 5 \mathrm{~m}^{2}$ were sown on 29 May (factor 5).

Experiment II. Sugar-beets 'Bingo' were sown on 25 April 1986 on a riverclay soil at the Haarweg in Wageningen. Each combination of the experimental factors 1 to 4 was of applied to four duplicate rows of 8 to 10 plants. To inoculate a plant, 30,10 or $2 M$. persicae were used (factor 2 ). One or 4 leaves were inoculated (factor 3 ). Plots of at least $2.5 \times 5 \mathrm{~m}^{2}$ were sown on 26 or 28 May and on 3 July (factor 5 ).

Additional observations on the incubation period of BYV and BMYV were made in five other fields in single or duplicate rows of 15 to 30 plants.

Myzus persicae culture. Virus-free $M$. persicae from a clone named M3, were cultured in the glasshouse on leaf 3 and leaf 4 of 5 to 6-leaved oilseed rape plants, Brassica napus ssp. oleifera (leaf 1 is the first leaf following the cotyledons). Every day a new cohort of ()-24-hour-old nymphs was started. The temperature in the glasshouse varied between 18 and $30^{\circ} \mathrm{C}$ and the photoperiod was at least $16 \mathrm{~h}$ day ' . Because oilseed rape is immune to BMYV and BYV (Russell, 1965; Björling and Nilsson, 1966) no BMYV could be introduced into the $B Y V$ culture by aphids from rape. Oilseed rape is susceptible to beet western yellows virus (BWYV), which is closely related to BMY V, but this virus was not detected in periodical tests of $M$. persicae from the culture, using Physalis floridana as a test plant (Duffus, 1973).

Virus cultures. BYV and BMYV were maintained in beet in two insect-proof glasshouse compartments located at $200 \mathrm{~m}$ distance from cach other. The strain of BYV used causes moderately-severe symptoms, viz. vein clearing in young leaves and necrotic spots on fully mature leaves (Björling, 1961). To keep the BY V-culture free from possibly contaminating BMYV, the virus was periodically transmitted to healthy plants either by A. fabae, which does not or hardly transmit BMYV, or by $M$. persicae using a 4-hour acquisition access period, immediately followed by a 4-hour inoculation access period. In such a sequence BMYV is not transmitted (Russell, 1962; Björling and Nilsson, 1966). BYV-infections in the BMYV-culture were not observed during the whole investigation. Occasionally, symptoms resembling those of BMYV were noticed on BYV-inoculated plants in the field, but BMYV was never recovered, using $M$. persicae as a vector and sugar-beet or C. bursa-pastoris as test plants.

Inoculation. When available, viruliferous $M$. persicae were taken from virus-infected beet plants in the glasshouse. During the summer, however, the glasshouse populations on bect collapsed so that other methods had to be used to produce viruliferous aphids.

In 1985, M. persicae from rape were brushed onto detached BYV-or BMYV-infected beet leaves lying in large Petri dishes or standing with their petioles upright in small bottles in glass jars. The dishes and jars were closed with poly-ethene foil or cheesecloth and their walls were coated with Fluon to prevent aphids from escaping. After 2 or 3 days, the aphids were transferred to the field in aphid-proof clip-cages. Aphids in these cages had to pass a $200 \mu \mathrm{m}$ mesh nylon gauze with their stylets to reach the leaf. Only about $10 \%$ of the inoculated plants became infected.

Neth. J. Pl. Path. 95 (1989) 
In 1986, adult $M$. persicae from rape were clip-caged onto yellow leaves of BYVinfected sugar-beet plants in the glasshouse. BMYV-infected aphids were cultured on infected shepherd's-purse. The aphids were caged onto plants in the field in non-aphidproof clip-cages (Adams and Van Emden, 1972). Using this method, about $90 \%$ of the plants became infected.

After an inoculation access period of 1 or 2 days, the aphids were killed manually. The plants were sprayed with the carbamate-insecticide pirimicarb. In June 1985 aldicarb granules were added to the soil because prolonged rainy weather hindered the application of foliar insecticides. During summer, the inoculated plots were treated weekly with insecticides, pirimicarb or oxy-demeton-methyl, to control immigrant aphids and limit virus spread from the inoculated plants.

Recording of symptoms. In 1985, the infected plants were inspected for symptoms weekly, if possible with cloudy weather as symptoms are easily overlooked in direct sunlight. In 1986, the inspections were made at intervals increasing from 4 to 5 days in June to 10 days in October. In these inspections, inoculated leaves, which were marked with a plastic label around the petiole, were distinguished from systemically-infected ones. Systemic symptoms which were readily discernible at a meter distance were evaluated positively. Inoculated leaves were judged with the same criterion, lifting healthy leaves covering inoculated ones if necessary. In some plots in Experiment II, the time needed for the development of vein clearing symptoms of BYV was determined.

Selection of plants for analysis. In the type of field study described here, precautions must be taken to exclude naturally-infected plants from the analysis. A plant was included in the analysis if four criteria were met:

(1) symptoms of the inoculated virus present on the inoculated leaf,

(2) no symptoms on leaves already mature on the infection-date, other than the inoculated one,

(3) normal phyllotactic pattern of systemic symptoms, viz. the first and most severe symptoms appearing on a leaf implanted above the inoculated leaf (Van der Werf et al., 1989a), and

(4) no virus infection in neighbouring non-inoculated plants.

Because $M$. persicae was scarce in 1985 , only a few plants had to be excluded, most of them in late-sown plots. In 1986, some plants were excluded in early-sown plots and all of six plots sown in July.

Data analysis. Proportions of plants showing symptoms for the first time were plotted against time to determine the median incubation period. Plants from different plots with the same treatment were lumped in this analysis, ignoring minor differences in incubation period between plots. To assess the variation in incubation period between plants, logistic growth curves were fitted to the data obtained in Experiment II:

$$
p=1 /\left(1+\mathrm{e}^{-(1-\mu) / s}\right)
$$

equivalent with

$$
\ln (p /(1-p))=(t-\mu) / s
$$

in which $p$ is the proportion of plants showing symptoms, $t$ is time since inoculation, 


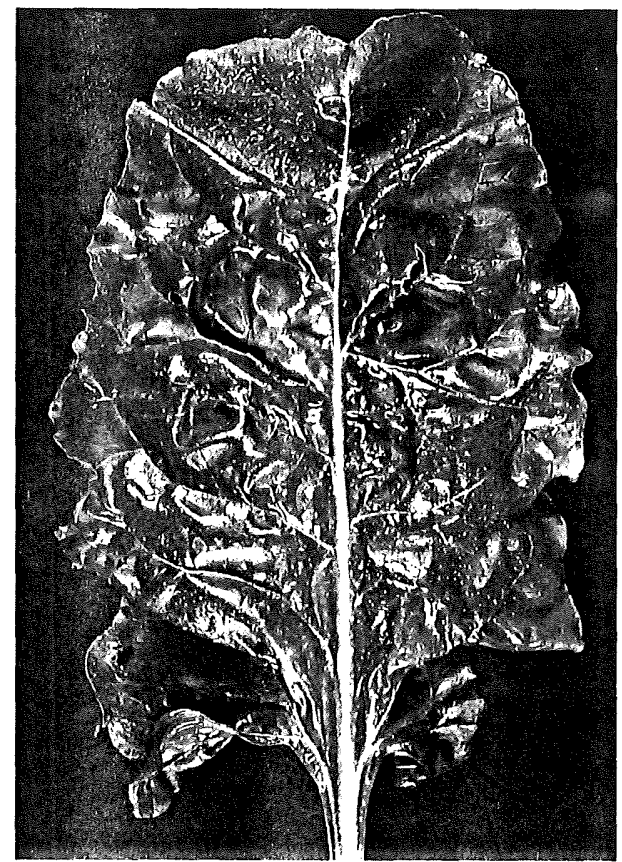

Fig. 1. Yellow spot on leaf inoculated with beet yellows virus; photograph taken on 6 September 1985.

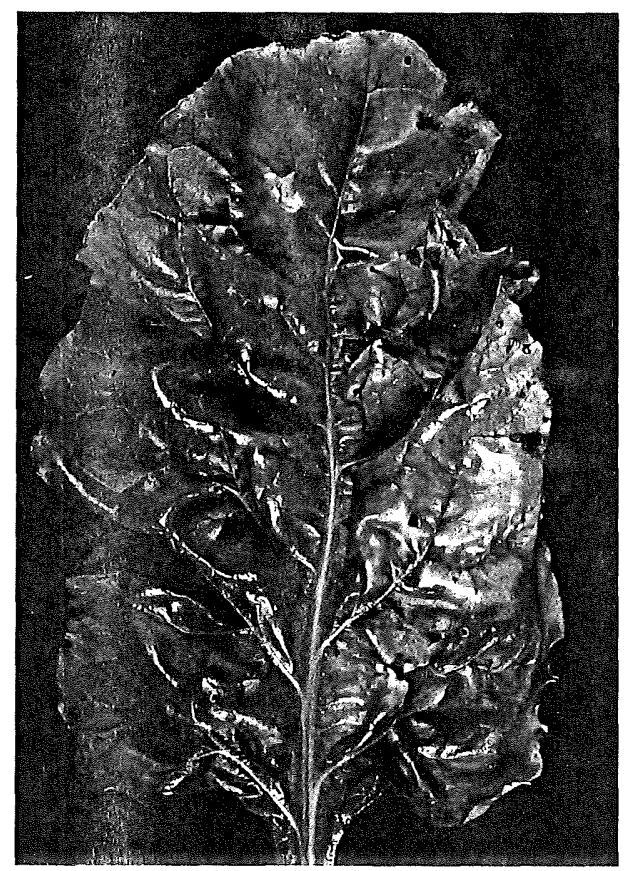

Neth. J. Pl. Path. 95 (1989)

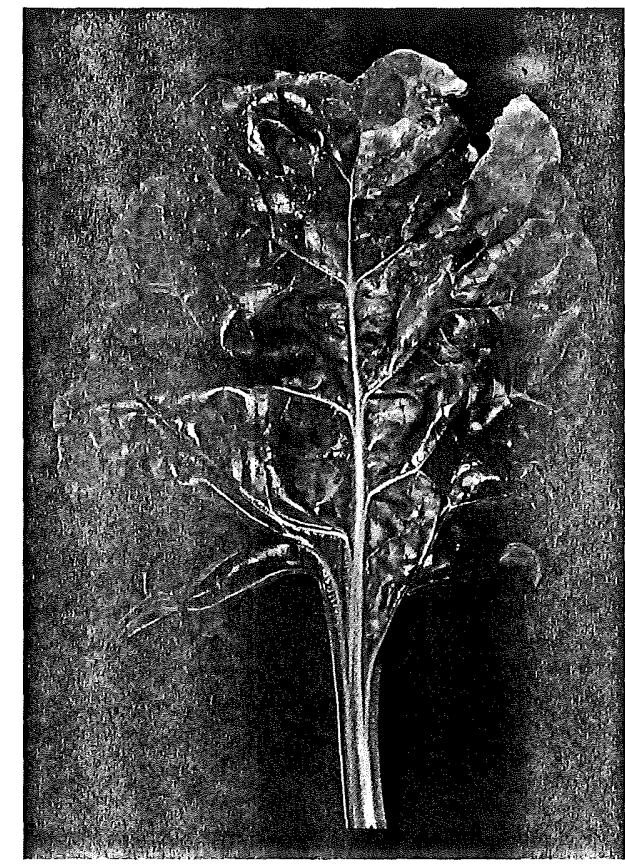

Fig. 2. Basipetal development of symptoms on sugar-beet leaf inoculated with beet yellows virus; photograph taken on 6 September 1985.

Fig. 3. Acropetal development of symptoms on sugar-beet leaf inoculated with beet mild yellowing virus; photograph taken on 6 September 1985. 
$\mu$ is the median incubation period and $s$ is the scale parameter of the logistic distribution. The parameters $\mu$ and $s$ were calculated by least squares regression of logit-values, $\ln (p /(1-p))$, on time (Zadoks and Schein, 1979). The standard deviation of the incubation period was obtained by multiplying the scale parameter $s$ with the standard deviation of the logistic distribution, $\pi / \sqrt{3}$ :

$$
\sigma=s \times \pi / \sqrt{3}
$$

Measurements of leaf growth. In Experiment II, leaf growth was measured with a ruler on 10 healthy plants sown on 25 April and on 10 plants sown on 26 May. For each leaf, leaf expansion was calculated relative to final length. Relative leaf growth curves were averaged for leaves appearing on approximately the same day. Leaves were taken to reach final length at the $95 \%$-point of the average relative leaf growth curve (Milford et al., 1985b).

\section{Results}

Development of symptoms during the season. Leaves inoculated with BYV or BMYV in May or June generally developed symptoms on a large portion of the blade within one or a few weeks, while those inoculated in July and August developed only a small yellow spot which expanded slowly (Fig. 1). Throughout the season, BYV-and BMYVsymptoms on inoculated leaves differed from each other in that BYV-symptoms mostly expanded basipetally along the midvein (Fig. 2) while those of BMYV spread acropetally along the leaf margin (Fig. 3). Areas with BYV-symptoms were often more sharply bordered by veins ('sectors'; Figs. 1 and 2) than those of BMYV. Local BYV-symptoms became often brighter yellow than systemic symptoms, thus resembling those of BMYV. The spots typical for BYV-infection became larger on the inoculated leaves than on the systemically-infected ones and exhibited a red colour instead of brown.

The brightest yellowing symptoms, especially those of BMYV, were observed when the plants were grown under cool conditions, e.g. in a cooled glasshouse or at the end of the season, while vaguer symptoms developed under warm conditions in the glasshouse or in the field in mid-summer. However, necrosis and vein clearing, caused by BYV, was more pronounced at high temperatures.

The incubation period increased during the growing season (Fig. 4). Symptoms of BYV appeared in 3 weeks on plants infected in May or the first two decades of June, while the incubation period gradually increased with plant age after canopy closure, at the end of June. Plants inoculated at the end of August showed local BY V-symptoms after 6 to 7 weeks and systemic symptoms after 9 weeks. When plants were infected with BMYV in May or June, local symptoms appeared after 3 to 4 weeks while systemic symptoms developed about a week later. In the course of the season the incubation periods of local and systemic BMYV-symptoms increased to 5 and 9 weeks, respectively.

Effect of inoculation conditions. The incubation period of systemic BY V-and BMYVsymptoms was not significantly affected by inoculation conditions, such as (1) the number of vector aphids, $M$. persicae; (2) the number of leaves inoculated; $(3)$ the development stage of the inoculated leaf or (4) the source plant of BMYV, beet or shepherd's-purse (Tables 1 and 2). Though inoculation conditions have a small but significant effect on the incubation period under controlled conditions (Björling, 1963), 

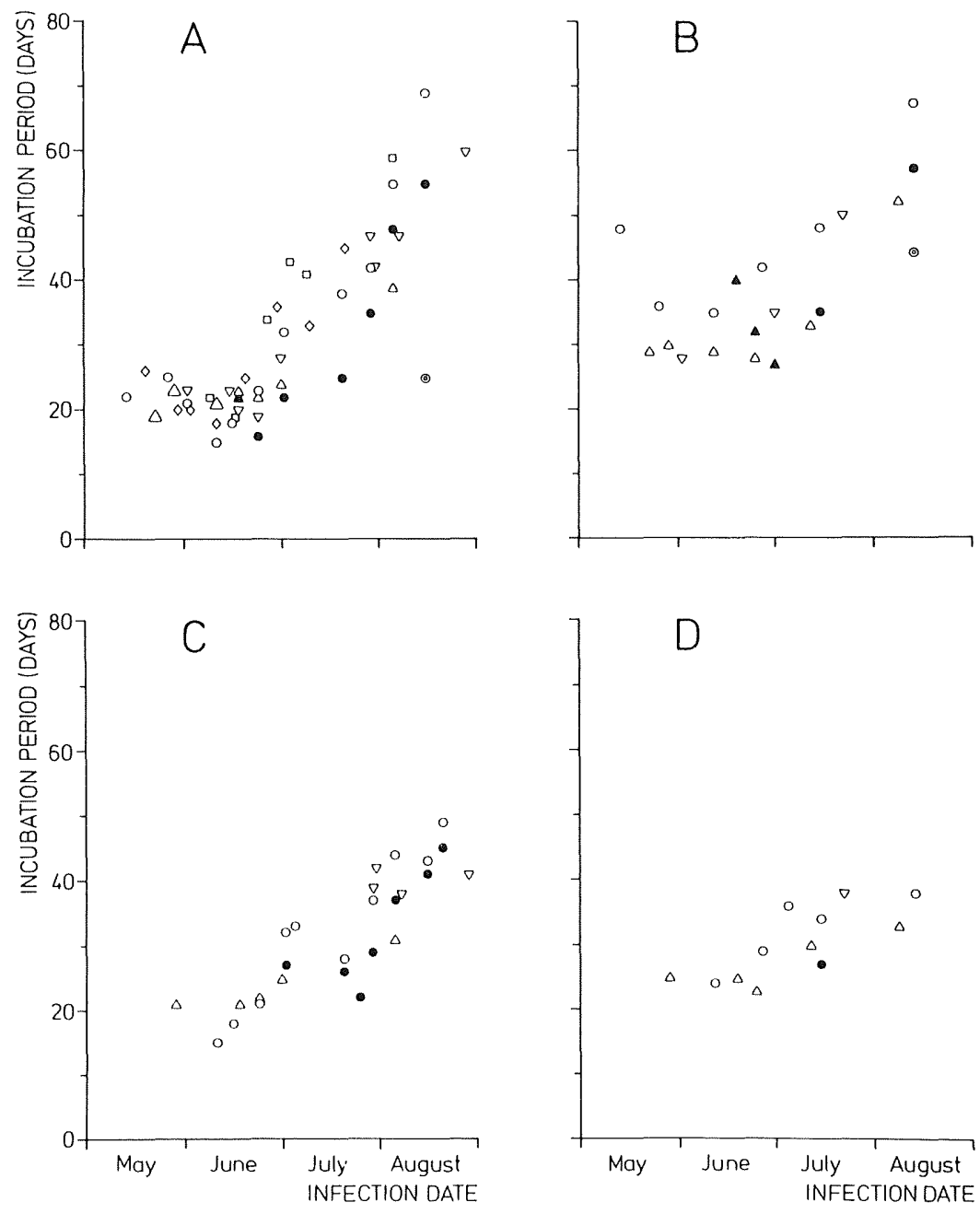

Fig. 4. Incubation period of local and systemic symptoms of beet yellows virus and beet mild yellowing virus during the growing season. Open symbols denote crops sown in April and solid symbols denote crops sown in May. One observation was made on plants sown in July (6). A: beet yellows virus, systemic symptoms; B: beet mild yellowing virus, systemic symptoms; C: beet yellows virus, local symptoms; D: beet mild yellowing virus, local symptoms. Observations were made in Wageningen in 1985 (Experiment I; د, 4), in Wageningen in 1986 (Experiment II; O, - , ...), in sugar-beet 'Bingo' growing on heavy river-clay near Randwijk in 1986 ( $\square$ ), in sugarbeet 'Regina' growing on sea-clay in the Flevopolder in $1986(\diamond)$ or in other beet crops growing on clay-soils in 1984 and $1985(\Delta)$.

the size of these ef fects appears to be small compared to the variation between plants in the field. These influences can therefore be neglected in field studies. The few plants successfully inoculated with BYV by $A$. fabae developed symptoms at the same time and with the same intensity as those inoculated by $M$. persicae.

Neth. J. Pl. Path. 95 (1989) 
Table 1. Influence of inoculation conditions on incubation period of systemic beet yellows virussymptoms (data from Exp. II; see text).

\begin{tabular}{|c|c|c|c|c|c|c|c|c|c|c|c|c|c|c|}
\hline \multicolumn{3}{|c|}{ Inoculation conditions } & \multicolumn{12}{|c|}{ Inoculation-date } \\
\hline \multirow{2}{*}{$\begin{array}{l}\text { number of } \\
M \text {. persicae } \\
\text { per plant }\end{array}$} & \multirow{2}{*}{$\begin{array}{l}\text { develop- } \\
\text { ment } \\
\text { stage of } \\
\text { inoculated } \\
\text { leaf }\end{array}$} & \multirow{2}{*}{$\begin{array}{l}\text { number } \\
\text { of in- } \\
\text { oculated } \\
\text { leaves }\end{array}$} & \multicolumn{3}{|c|}{$11 / 12$ June } & \multicolumn{3}{|c|}{24 June } & \multicolumn{3}{|c|}{29 July } & \multicolumn{3}{|c|}{15 August } \\
\hline & & & $\hat{\mu}^{\prime \prime}$ & $\hat{\sigma}^{21}$ & $n^{31}$ & $\hat{\mu}$ & $\hat{\sigma}$ & $n$ & $\hat{\mu}$ & $\hat{\sigma}$ & $n$ & $\hat{\mu}_{25}^{41}$ & $\hat{\sigma}$ & $\mathrm{n}$ \\
\hline 10 & expanding & 1 & 15 & 2.0 & 60 & 24 & 3.1 & 40 & 42 & 5.4 & 23 & 58 & 11.6 & 17 \\
\hline 10 & full-grown & 1 & 16 & 2.0 & 32 & 22 & 3.1 & 39 & 43 & 5.4 & 27 & - & - & - \\
\hline 10 & ageing & 1 & 15 & 2.0 & 31 & 24 & 3.1 & 29 & 48 & 5.4 & 19 & - & - & - \\
\hline 10 & all stages & 4 & 15 & 2.0 & 27 & $-5)$ & - & - & - & - & - & 53 & 11.6 & 42 \\
\hline 2 & expanding & 1 & 15 & 2.0 & 26 & - & - & - & 42 & 5.4 & 21 & - & - & - \\
\hline 30 & expanding & 1 & 14 & 2.0 & 32 & - & - & - & 40 & 5.4 & 21 & - & - & - \\
\hline
\end{tabular}

Table 2. Influence of inoculation conditions on incubation period of systemic beet mild yellowing virus-symptoms (data from Exp. II; see text).

\begin{tabular}{|c|c|c|c|c|c|c|c|c|c|c|c|c|}
\hline \multicolumn{4}{|c|}{ Inoculation conditions } & \multicolumn{9}{|c|}{ Inoculation-date } \\
\hline \multirow{2}{*}{$\begin{array}{l}\text { number of } \\
M \text {. persicae } \\
\text { per plant }\end{array}$} & \multirow{2}{*}{$\begin{array}{l}\text { develop- } \\
\text { ment } \\
\text { stage of } \\
\text { inoc- } \\
\text { ulated } \\
\text { leaf }\end{array}$} & \multirow{2}{*}{$\begin{array}{l}\text { number } \\
\text { of inoc- } \\
\text { ulated } \\
\text { leaves }\end{array}$} & \multirow{2}{*}{$\begin{array}{l}\text { virus } \\
\text { source } \\
\text { plant }\end{array}$} & \multicolumn{3}{|c|}{$12 / 13 \mathrm{July}$} & \multicolumn{3}{|c|}{15 July } & \multicolumn{3}{|c|}{13 August } \\
\hline & & & & $\hat{\mu}$ & $\hat{\sigma}$ & $\mathrm{n}$ & $\hat{\mu}$ & $\hat{\sigma}$ & $\mathrm{n}$ & $\hat{\mu}_{25}$ & $\hat{\sigma}$ & $\mathrm{n}$ \\
\hline 10 & expanding & 1 & beel & 33 & 4.5 & 25 & 49 & 6.7 & 28 & 58 & 8.5 & 25 \\
\hline 10 & full-grown & 1 & beet & 32 & 4.5 & 22 & 49 & 6.7 & 13 & - & - & - \\
\hline 10 & agcing & 1 & bect & 36 & 4.5 & 22 & - & - & - & - & - & - \\
\hline 10 & all stages & 4 & beet & - & - & - & - & - & - & 67 & 8.5 & 16 \\
\hline 2 & expanding & 1 & beet & 35 & 4.5 & 14 & 43 & 6.7 & 9 & - & - & - \\
\hline 30 & expanding & 1 & beet & 35 & 4.5 & 30 & - & - & - & - & - & - \\
\hline 10 & expanding & 1 & Capsella & - & - & - & 51 & 6.7 & 9 & 58 & 8.5 & 7 \\
\hline
\end{tabular}

For explanation of symbols see Table 1.

Effect of plant age and temperature. May-sown plants exhibited shorter incubation periods than April-sown plants throughout the growing season while plants sown in July developed symptoms most rapidly throughout the season (Figs. 5 and 6). Apparently, the age of the plant affects the incubation period for both categories of infected leaves. High temperature accelarates the development of symptoms. For example, 10-leaved plants sown on 25 April 1986 (Experiment II) and inoculated with BYV on 16 June, showed symptoms after 18 days at an average temperature of $22{ }^{\circ} \mathrm{C}$, while 

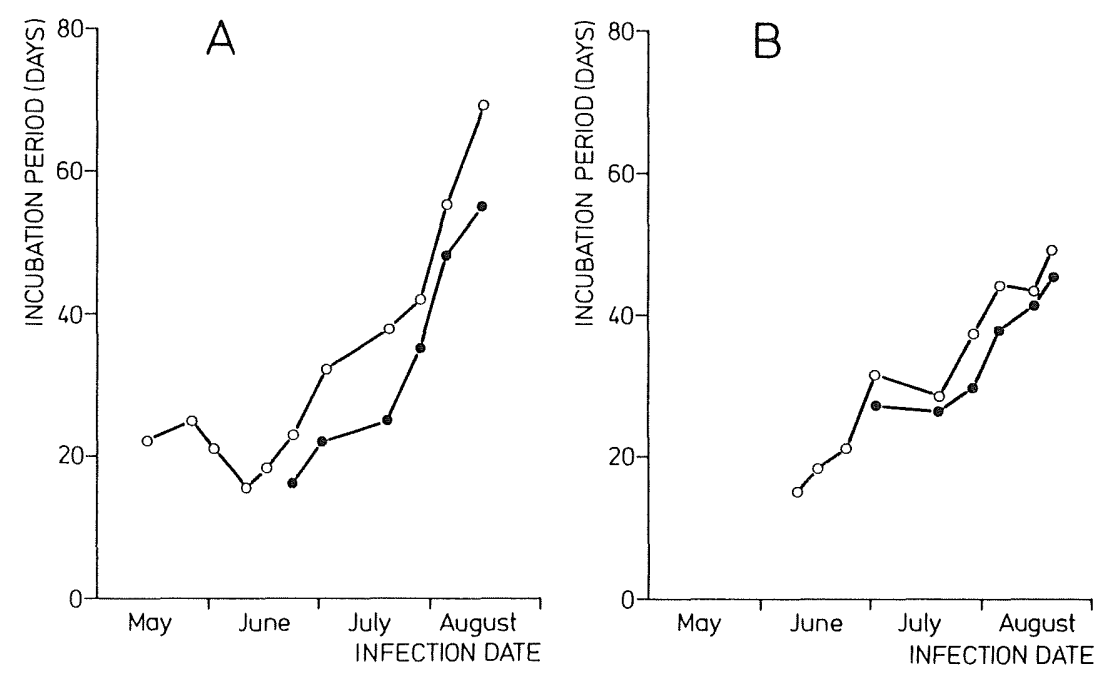

Fig. 5. Effect of sowing date, 25 April ( O ) or 26/28 May ( ), on the incubation period of (A) systemic and $(B)$ local beet yellows virus-symptoms throughout the season. Data from Experiment II (see text).
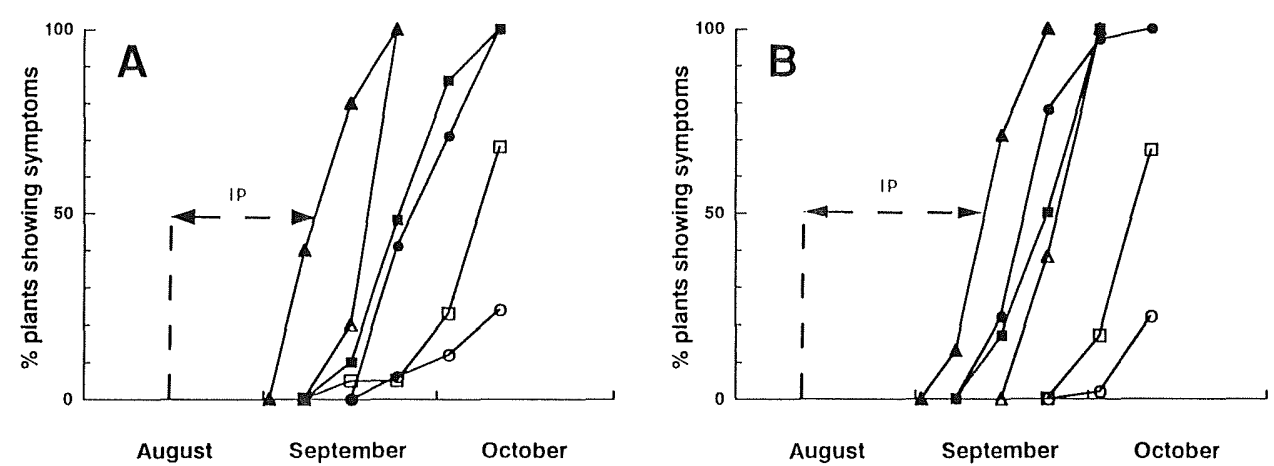

Fig. 6. Effect of plant age on the appearance of symptoms of $(\mathrm{A})$ beet yellows virus, inoculated on 15 August and (B) beet mild yellowing virus, inoculated on 13 August 1986. Sowing dates: 24 April $(0,-), 28$ May $(\square,-$ ) and 3 July (\lrcorner$, \mathbf{\Delta})$. Open symbols refer to systemic symptoms while solid symbols denote local symptoms. The median incubation period (IP) of local symptoms on plants sown in July is indicated by the horizontal hatched arrows. Data from Experiment II (see text).

10-leaved plants sown on 3 July and inoculated on 15 August showed symptoms after 35 days at temperatures averaging $10^{\circ} \mathrm{C}$. Allowing for the temperature effect by expressing the incubation period in ${ }^{\circ} \mathrm{C}$ days (De Wit and Goudriaan, 1978) shows that the thermal incubation periods were approximately similar, $253{ }^{\circ} \mathrm{C}$ days for the plants inoculated on $16 \mathrm{June}$ and $292{ }^{\circ} \mathrm{C}$ days for those inoculated on 15 August. Thus, it is shown that temperature and plant age are major factors determining the incubation period. Fig. 7 combines the influences of temperature and plant age, as indexed by the Neth. J. Pl. Path. 95 (1989) 

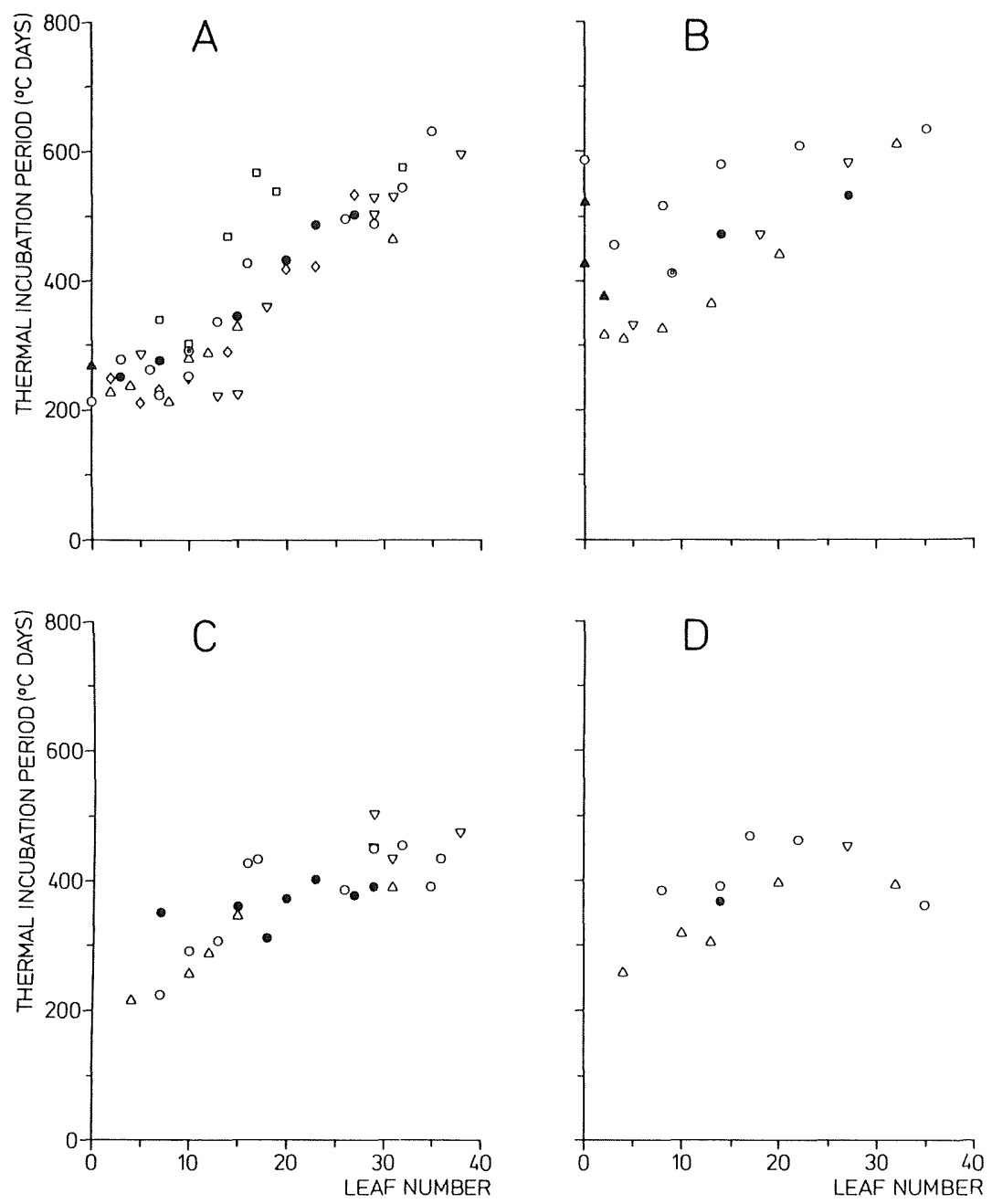

Fig. 7. Thermal incubation period $\left({ }^{\circ} \mathrm{C}\right.$ days above $\left.3{ }^{\circ} \mathrm{C}\right)$ of beet yellows virus and beet mild yellowing virus in sugar-beet as a function of plant leaf number on the inoculation-date. Meaning of symbols and lettering as in Fig. 4.

number of leaves on the plant, on the incubation period, showing that a good relation exists between plant leaf number and the thermal incubation period.

Relation between symptom expression and leaf expansion. The first leaves to show symptoms of systemic infection by yellowing viruses are those that just appear ( $\geq 3$ $\mathrm{cm}$ ) at the moment of inoculation (Van der Werf et al., 1989a). The course of the incubation period during the growing season showed much the same trend as the duration of blade expansion of newly appearing leaves, as measured on healthy plants (Fig. 8). Incipient symptoms of BYV were observed when leaves of the same age on healthy plants approached final length. A week later, the symptoms were evaluated as 'clear'. Incipient 

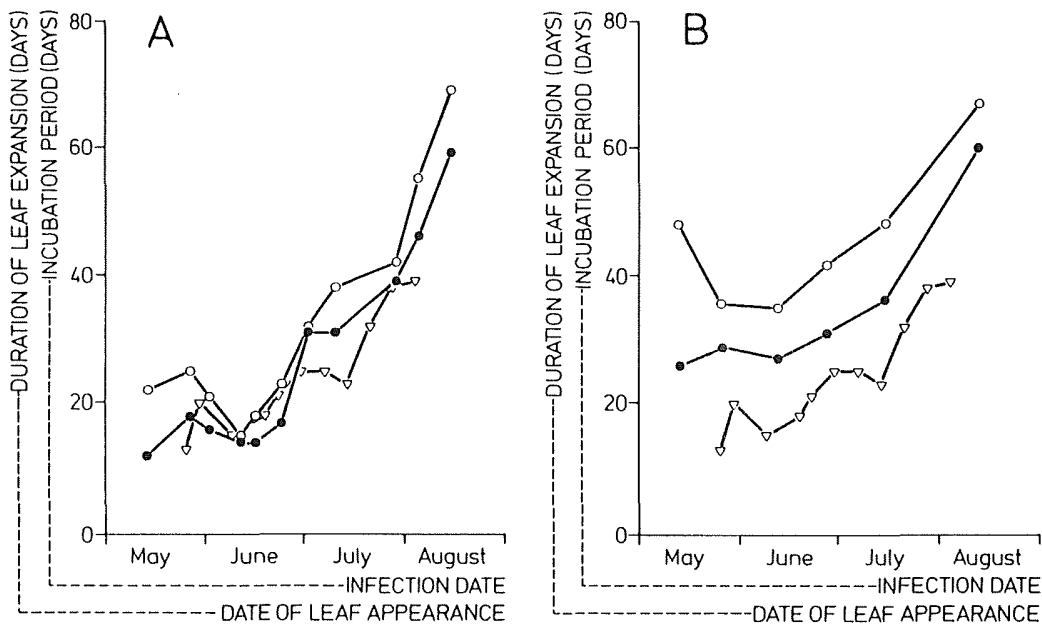

Fig. 8. Duration of leaf expansion $(\Gamma)$ and incubation period of incipient $(\bullet)$ and clear $(0)$ systemic symptoms of $(A)$ bect ycllows virus or $(B)$ beet mild yellowing virus in sugar-beet during the growing season. Data from Experiment II (see text).

symptoms of BMY V were noticed one to two weeks after completion of leaf expansion on healthy plants, while it took another one to two weeks before symptoms became clearly visible. These results suggest that physiological conditions characteristic for fully-expanded leaves are prerequisite for the development of symptoms. Furthermore, these results suggest that the low leaf expansion rate in old plants and at low temperatures is the underlying reason for the longer incubation period under these conditions.

The long incubation period in plants infected with BMYV in the cotyledon stage is another example of the relationship between symptom development and leaf expansion. Groups of plants sown on 29 May 1985 (Exp. I) were inoculated with BMYV on 19 June, 25 June or $1 \mathrm{July}$ when they were in the early cotyledon stage, late cotyledon stage and the 2-leaf-stage, respectively (growth stages according to Lutman and Tucker, 1987). The plants of these three groups showed symptoms simultaneously around 31 July when leaf 3 and 4 attained their final size. Vague symptoms were seen earlier on leaf 1 and 2 but these short-lived leaves (Milford et al., 1985a) died before clear symptoms developed.

Vein clearing. In Exp. II, vein clearing appeared $50-60^{\circ} \mathrm{C}$ days before leaf yellowing symptoms, throughout the season (Fig. 9). The relation between thermal incubation period and plant age (leaf number) is independent of sowing date (Fig. 9).

Variation between plants. Fig. 10 shows the time-course of symptom development in Experiment II. The development of symptoms in groups of inoculated plants is adequately described with logistic growth curves, such that the variability of the incubation period among plants can be estimated with Eq. 3 (Table 3). The largest variation between plants is obtained when the incubation period is long, at the end of the season. The coefficient of variation of the incubation period ranges from $5 \%$ to $24 \%$ 


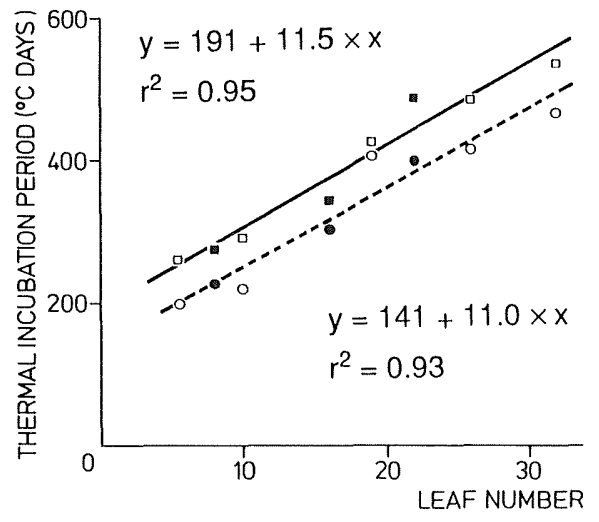

Fig. 9. Comparison of the temperature sum needed for the development of vein clearing $(\square$, 田; hatched line) and yellowing symptoms ( 0 , - ; solid line) after inoculation with beet yellows virus. Data from Experiment II (see text). Plants sown on 25 April denoted by open symbols and those sown on 26 May by solid ones.

Table 3. Incubation period of systemic symptoms of infection by beet yellows virus and beet mild yellowing virus in relation to sowing date (Data from Experiment II; see text).

\begin{tabular}{|c|c|c|c|c|c|c|c|c|c|c|c|c|}
\hline \multirow[t]{3}{*}{ Inoculation-date } & \multicolumn{12}{|c|}{ Virus; sowing date } \\
\hline & \multicolumn{4}{|c|}{ BYV; 25 April } & \multicolumn{4}{|c|}{ BMYV; 25 April } & \multicolumn{4}{|c|}{ BYV; 26/28 May } \\
\hline & $\hat{\mu}^{1)}$ & $\hat{\sigma}^{2)}$ & $C V^{3)}$ & $n^{4)}$ & $\hat{\mu}$ & $\hat{\sigma}$ & $\mathrm{CV}$ & $\mathrm{n}$ & $\hat{\mu}$ & $\hat{\sigma}$ & $\mathrm{CV}$ & $\mathrm{n}$ \\
\hline 14 May & 25 & 4.5 & 18 & 18 & 51 & 3.6 & 7 & 11 & $-5)$ & - & - & - \\
\hline $26 \& 27$ May & 23 & 2.5 & 11 & 21 & 37 & 4.5 & 12 & 22 & - & - & - & - \\
\hline 2 June & 22 & 1.1 & 5 & 43 & - & - & - & - & - & - & - & - \\
\hline $11-13$ June & 17 & 2.0 & 12 & 208 & 33 & 4.5 & 12 & 143 & - & - & - & - \\
\hline 16 June & 22 & 3.8 & 17 & 25 & - & - & - & - & - & - & - & - \\
\hline 24 June & 23 & 3.1 & 13 & 108 & - & - & - & - & 14 & 2.2 & 15 & 44 \\
\hline 27 June & - & - & - & - & 43 & 2.9 & 7 & 31 & - & - & - & - \\
\hline 2 July & 35 & 3.4 & 10 & 82 & - & - & - & - & 26 & 4.4 & 17 & 37 \\
\hline $15 \mathrm{July}$ & - & - & - & - & 46 & 6.7 & 15 & 54 & - & - & - & - \\
\hline $20 \mathrm{July}$ & 37 & 2.9 & 8 & 87 & - & - & - & - & 25 & 2.7 & 11 & 46 \\
\hline 25 July & - & - & - & - & - & - & - & - & 29 & 6.9 & 24 & 19 \\
\hline 29 July & 44 & 5.4 & 12 & 97 & - & - & - & - & 36 & 8.5 & 24 & 22 \\
\hline 5 August & 58 & 5.8 & 10 & 85 & - & - & - & - & 48 & 4.9 & 10 & 79 \\
\hline $13 \& 15$ August & 63 & 11.6 & 18 & 31 & 66 & 8.5 & 13 & 45 & 56 & 12.5 & 22 & 22 \\
\hline average $\mathrm{CV}$ & & & 12 & & & & 18 & & & & 11 & \\
\hline
\end{tabular}

1) $\hat{\mu}=$ average incubation period (days), determined according to Eq. 2 .

2) $\hat{\sigma}=$ standard deviation of incubation period, determined according to Eqs $2 \& 3$.

3) $\mathrm{CV}=$ variation coefficient $(\%)$.

4) $\mathrm{n}=$ number of plants observed.

5) No observations.

in this experiment with an average value of $13 \%$. This considerable variation among plants is a source of error when estimates of the incubation period are used to determine infection-dates of single plants. 

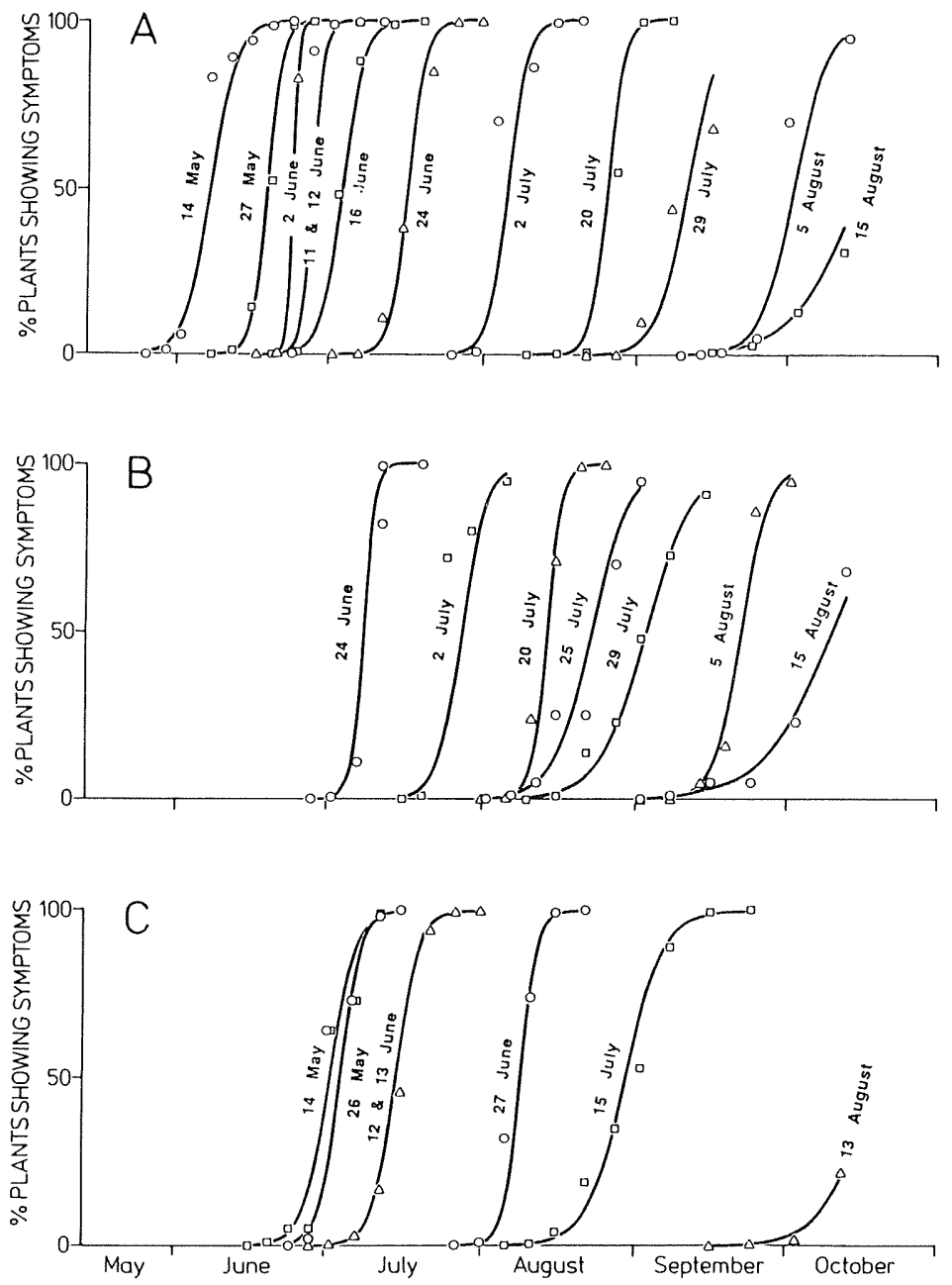

Fig. 10. Time-course of the development of systemic beet yellows virus-symptoms on plants sown on 25 April (A) or 26/28 May 1986 (B) and of systemic beet mild yellowing virus-symptoms on early-sown plants (C), inoculated at different dates. The symbols $\circ, \square$ and $\Delta$ denote observations made on batches of plants inoculated at subsequent dates. Data from Experiment II (see text).

\section{Discussion}

Incubation periods observed in this study range from less than 3 weeks to more than 9 weeks, confirming the large variation reported in the literature. The present study shows that plant age is the major factor responsible for this variability (Figs. 5 and 6). Glasshouse experiments in sugar-beet by Duffus and Skoyen (1977) show a similar effect of plant age on symptom development of beet curly top virus. In our field experiments, temperature is the second important factor determining the length of the

Neth. J. Pl. Path. 95 (1989) 
incubation period, confirming glasshouse studies of Wiesner (1959) and Björling (1963). Ageing of the plants and low temperature explain the long incubation period of yellowing viruses at the end of the season. Two other factors affecting the incubation period are the causal virus, BYV or BMYV, and the nature of the infection, local or systemic (Fig. 4).

Inoculation conditions, such as vector number and species did not substantially affect the incubation period, in contradiction to reports by Steudel (1958) and Thielemann and Nagi (1977). These authors made their observations in field plots, failing to take precautions to exclude naturally-infected plants from their analyses. The inability to distinguish between experimentally- and naturally-infected plants results in an overestimation of the incubation period if a partly successful inoculation is followed by natural spread. Such an erroneous result is likely to be obtained when an inefficient vector is used, e.g. Aphis fabae (Thielemann and Nagi, 1977), or when low numbers (1 or 2) of efficient vectors, M. persicae, are used (Steudel, 1958). Therefore, it is better, though laborious, to make observations of the incubation period on individual plants in stead of whole plots. In studies with individual plants (Björling, 1963; this study) effects of vector species or number on the incubation period were negligible. The other inoculation conditions studied, age and number of inoculated leaves, did not influence the incubation period.

A considerable variation in incubation period was found between individual plants (Fig. 10; Table 2), probably as a result of differences in heritable properties and growing conditions. Differences in incubation period were also observed among different fields (Figs. 4 and 7). For instance, plants grown near Randwijk in 1986 exhibited a long thermal incubation period (Fig. 7A), probably because drought retarded leaf expansion. Though care was taken to judge with the same criterion in all experiments, inconsistencies in the evaluation of the symptoms could also have made a minor contribution to field to field differences in incubation period.

Because inoculation conditions do not affect the incubation period, estimates of the latter can be used to assess the infection-date, based on observations of the appearance of the first symptoms. In doing so, systemic symptoms should be looked after as local symptoms are easily overlooked. Results from this study may be used as a reference. For this purpose, the infection-date is plotted against the date on which symptoms were first observed in Fig. 11. The formulas given in the legend of the figure yield a point estimate of the infection-date while the hatched lines indicate a $95 \%$ confidence interval. The width of the interval is 2 à 3 weeks, indicating considerable uncertainty with respect to the infection-date estimated by means of the incubation period. For early BMY V-infections the uncertainty is even greater than 2 à 3 weeks. In this situation, another method for estimation of the date of infection, based on the position of yellow leaves on the plant (Van der Werf et al., 1989a), may provide a useful alternative. Estimates of the infection-date can be improved by making reference observations in the same crop because $\hat{\sigma}_{\mathrm{R}}$ can then be neglected (see legend Fig. 11). In that case $95 \%$ confidence intervals for the infection-date are only 1 à 2 weeks wide, giving sufficient accuracy for application in field studies of virus spread.

Possible mechanisms underlying the longer incubation period in older plants, e.g. delayed virus translocation or retarded multiplication, are discussed in a following paper (Van der Werf et al., 1990). 

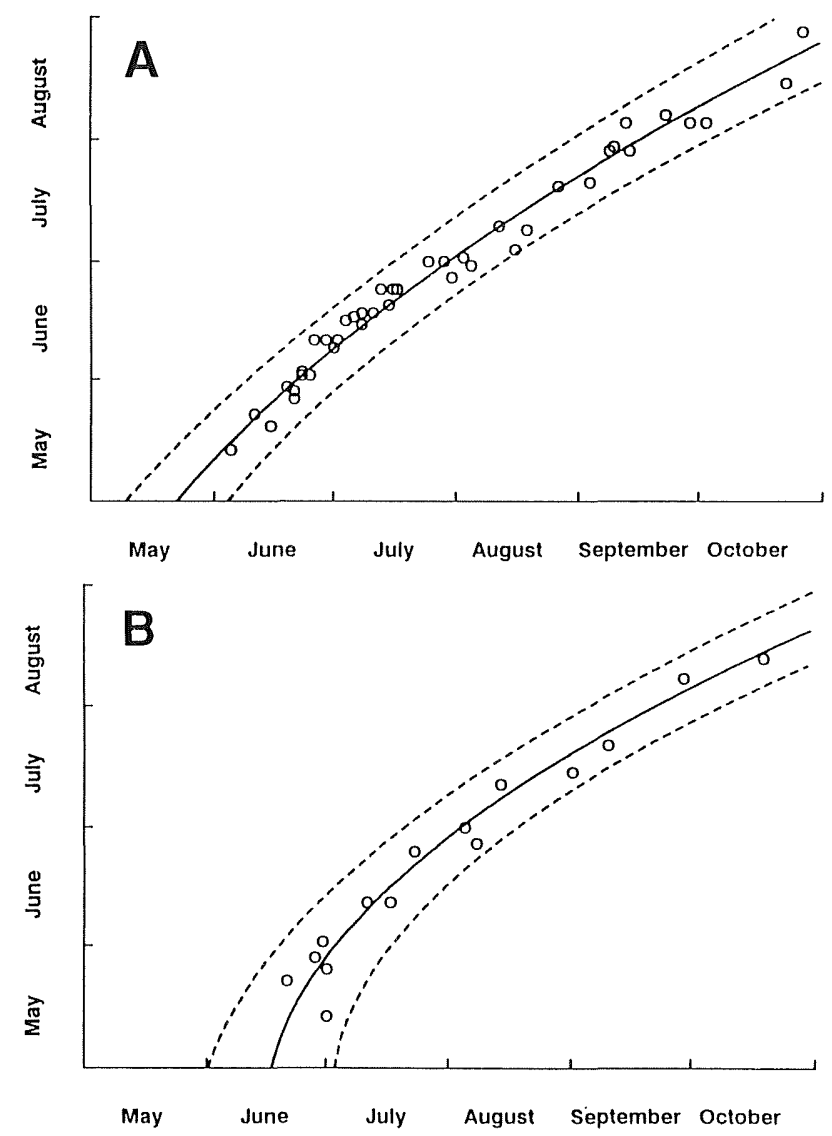

Fig. 11. Estimated date of infection (Y) with beet yellows virus (Fig. 11A) or beet mild yellowing virus (Fig. 11B) as a function of the date on which systemic symptoms are first observed (X), with $95 \%$ confidence intervals. Open circles denote observed median dates of symptom expression in April-sown crops (cf. Fig. 4). Drawn lines are defined by:

beet yellows virus: $\quad \mathrm{Y}=35+14.4 \times \sqrt{\mathrm{X}-107}$

beet mild yellowing virus: $\quad Y=107+10.7 \times \sqrt{X-167}$

These equations were obtained by inverting curvilinear least squares regression lines, relating $\mathrm{X}$ to $\mathrm{Y}$ :

beet yellows virus:

$$
\mathrm{X}=113-0.340 \times \mathrm{Y}+0.00484 \times \mathrm{Y}^{2} \quad r^{2}=0.98 \quad \hat{\sigma}_{\mathrm{R}}=5.6
$$

beet mild yellowing virus:

$$
\mathrm{X}=267-1.878 \times \mathrm{Y}+0.00878 \times \mathrm{Y}^{2} \quad r^{2}=0.98 \quad \hat{\sigma}_{\mathrm{R}}=6.1
$$

Reading horizontally in the figures, hatched lines demarcate $95 \%$ prediction regions for $X$, given $Y$. The width of these regions is:

$4 \times \sqrt{\sigma_{\mathrm{R}}^{2}+(\mathrm{CV} \times \mu)^{2}}$

where $\hat{\sigma}_{\mathrm{R}}^{2}$ is the average squared deviation between the observed average date of symptom expression and the regression line while $(\mathrm{CV} \times \mu)^{2}$ denotes the between-plants variance of the incubation period (Table 3; Fig. 10). Based on data obtained in 1985 (unpublished results) and 1986 (Table 3 ), the estimate of $\mathrm{CV}$ is 0.14 for beet yellows virus and 0.11 for beet mild yellowing virus. Vertical intervals between the hatched lines denote confidence regions for the infectiondate of single plants, given the date of symptom expression.

Neth. J. Pl. Path. 95 (1989) 


\section{Acknowledgements}

We thank Ir F. Bonnier, Ir J. Guan, Dr M. Hurej, Mrs Ir P.R. Westerman and J. Bendiek for their contributions to the work presented in this paper. The staff of the experimental farms 'De Minderhoudhoeve' near Swifterbant, 'De Bouwing' near Randwijk and the experimental farms on the Binnenhaven and the Haarweg in Wageningen are gratefully acknowledged for their help. Ir F.L. Dieleman, Wageningen Agricultural University, provided the M3 clone of $M$. persicae. Temperature recordings were made by the Department of Meteorology and Physics of the Wageningen Agricultural University, and Ir P. Kostense prepared most drawings. Dr G.D Heathcote, Dr A.M. Dewar, Prof. Dr Ir R. Rabbinge, Prof. Dr R.W. Goldbach and Mrs H.H. van Laar made useful remarks on the various versions of the paper. Dr M.A.J. van Montfort and Drs A. Otten gave advise on statistical matters. The publication of colour illustrations was made possible by financial help of the 'Fonds Landbouw Export Bureau 1916/1918'.

\section{Samenvatting}

De incubatieperiode van bietevergelingsvirussen in suikerbieten onder veldcondities

De incubatieperiode van het bietevergelingsvirus, BY V, en het zwakke-bietevergelingsvirus, BMYV, nam toe naarmate suikerbieteplanten later in het seizoen geinfecteerd werden. Jonge planten ontwikkelden BYV-symptomen na ongeveer 3 weken terwijl na gewassluiting de incubatieperiode geleidelijk toenam tot 9 weken. De incubatieperiode van BMYV nam toe van 4 à 5 weken na inoculatie in juni tot 9 weken na inoculatie in augustus. Geïnoculeerde bladeren ontwikkelden ongeveer een week eerder symptomen dan de systemisch geïnfecteerde bladeren, behalve bij jonge planten, geïnfecteerd met BYV, waar de symptomen zich op beide typen bladeren tegelijkertijd ontwikkelden.

De incubatieperiode nam bij hogere temperatuur af en, afhankelijk van de leeftijd van de plant (aantal bladeren), was een bepaalde temperatuursom nodig voor de ontwikkeling van symptomen. Deze temperatuursom nam toe met de ouderdom van de plant. Van alle systemisch besmette bladeren, vertoonden de oudste, welke juist verschenen op het moment dat de plant werd geïnfecteerd, als eerste symptomen. Dit gebeurde zodra of kort nadat ze hun uiteindelijke grootte hadden bereikt. Groeiende bladeren vertoonden nooit vergelingssymptomen. De trage bladexpansie in oude planten en bij lage temperaturen is een mogelijke oorzaak van de lange incubatieperiode aan het einde van het seizoen.

De incubatieperiode werd niet duidelijk beïnvloed door inoculatieomstandigheden, zoals (1) het aantal groene perzikluizen, Myzus persicae, dat werd gebruikt voor inoculatie, (2) het aantal geïnoculeerde bladeren, (3) de ouderdom van het geinoculeerde blad, (4) de bronplant van BMYV, biet of herderstasje, of (5) de vector species. Omdat de incubatieperiode niet in belangrijke mate afhankelijk is van deze factoren kan bij kennis van de datum waarop symptomen verschenen de infectiedatum worden bepaald op basis van de incubatieperiode.

\section{References}

Adams, J.B. \& H.F. Van Emden, 1972. The biological properties of aphids and their host plantrelationships. In: H.F. Van Emden (Ed.): Aphid technology. Academic Press, New York. 
Bar-Joseph, M., S.M. Garnsey \& D. Gonsalves, 1979. The closteroviruses: a distinct group of elongated plant viruse:s. Advances in Virus Research 25: 93-168.

Björling, K., 1952. On the significance of different vectors of sugar beet virus yellows. Acta Agriculturae Scandinavica II, 3: 258-278.

Björling, K., 1961. Stability of strains of sugar beet yellows virus and influence of host genotype on the symptoms. Socker Handlingar II, 17: 1-13.

Björling, K., 1963. Effect of different modes of vector inoculation on symptoms and yield reduction by beet yellows virus. Socker Handlingar II, 19: 1-23.

Björling, K., D. Lihnell \& F. Ossiannilsson, 1951. Marking viruliferous aphids with radioactive phosphorus. Acta Agriculturae Scandinavica I, 3: 301-317.

Björling, K. \& G. Möllerström, 1974. Incidence and importance of beet yellowing viruses in Sweden 1946 to 1973. Socker Handlingar 26: 1-14.

Björling, K. \& B. Nilsson, 1966. Observations on host range and vector relations of beet mild yellowing virus. Socker Handlingar II, 21: 1-14.

Bos, L., G.W. Ankersmit, W.A. Coolen, H.H. Evenhuis, Th. Limonard, J.E. Parlevliet \& W. van der Zweep, 1985. Lijst van gewasbeschermingskundige termen. Gewasbescherming 16 (Supp.): $1-64$.

Duffus, J.E., 1973. The yellowing virus diseases of bect. Advances in Virus Research 18: 347-386.

Duffus, J.E. \& I.O. Skoyen, 1977. Relationship of age of plants and resistance to a severe isolate of beet curly top virus. Phytopathology 67: 151-154.

Hall, A.E. \& R.S. Loomis, 1972a. An explanation for the difference in photosynthetic capabilities of healthy and beet yellows virus-infected sugar-beets (Beta vulgaris L.). Plant Physiology 50: $576-580$.

Hall, A.E. \& R.S. Loomis, 1972b. Photosynthesis and respiration by healthy and beet yellows virus-infected sugar-beets (Beta vulgaris L.). Crop Science 12: 566-571.

Häni, A., 1979. Die Vergilbungskrankheit bei Zuckerrüben in der Schweiz. Mitteilungen der Schweizerische Landwirtschaft 27: 15-21.

Heathcote, G.D., 1966. The time of flight and the relative importance of Myzus persicae (Sulz.) and Aphis fabae Scop. in relation to the incidence of beet yellows as shown by trap catches at Rothamsted and Broom's Barn. Bulletin of Entomological Research 56: 473-480.

Karl, E. \& I. Giersemehl, 1981. Untersuchungen zum Vectorartenspectrum des milden Rübenvergilbungs-Virus (beet mild yellowing virus). Archiv für Phytopathologie und Pflanzenschutz 17: 229-234.

Kershaw, W.J.S., 1965. The spread of yellows viruses in sugar-beet. Annals of Applied Biology 56: $231-241$

Lutman, P.J.W. \& G.G. Tucker, 1987. Standard descriptions of growth stages of annual dicotyledonous weeds. Annals of Applied Biology 110: 683-687.

Milford, G.F.J., T.O. Pocock \& J. Riley, 1985a. An analysis of leaf growth in sugar-beet. II. Leaf appearance in field crops. Annals of Applied Biology 106: 173-185.

Milford, G.F.J., T.O. Pocock, J. Riley \& A.B. Messem, 1985b. An analysis of leaf growth in sugarbeet. III. Leaf expansion in field crops. Annals of Applied Biology 106: 187-203.

Plank, J.E. van der, 1963. Plant diseases: epidemics and control. Academic Press, New York, $349 \mathrm{pp}$.

Ribbands, C.R., 1963. The spread of apterae of Myzus persicae (Sulz.) and of yellows viruses within a sugar-beet crop. Bulletin of Entomological Research 54: 267-283.

Roseboom, P.H.M. \& D. Peters, 1984. Detection of beet yellows virus in sugar-beet plants by enzyme-linked immunosorbent assay (ELISA). Netherlands Journal of Plant Pathology 90: 133-141.

Russell, G.E., 1958. Sugar beet yellows: a preliminary study of the distribution and interrelationships of viruses and virus strains found in East-Anglia, 1955-1957. Annals of Applied Biology 46: 393-398.

Russell, G.E., 1962. Sugar beet mild yellowing virus: a persistent aphid-transmitted virus. Nature

Neth. J. Pl. Path. 95 (1989) 
(London) 195: 1231.

Russell, G.E., 1963. Some factors affecting the relative incidence, distribution and importance of beet yellows virus and sugar-beet mild yellowing virus in eastern England, 1955-62. Annals of Applied Biology 52: 405-413.

Russell, G.E., 1964a. Breeding for tolerance to beet yellows virus and beet mild yellowing virus in sugar beet. I. Selection and breeding methods. Annals of Applied Biology 53: 363-376.

Russell, G.E., 1964b. Breeding for tolerance to beet yellows virus and beet mild yellowing virus in sugar-beet. II. The response of breeding material to infection with different virus strains. Annals of Applied Biology 53: 377-388.

Russell, G.E., 1965a. The host range of some English isolates of beet yellowing viruses. Annals of Applied Biology 55: 245-252.

Russell, G.E., 1965b. Observations on the epidemiology of sugar-beet virus yellows in eastern England in 1963 and 1964. Plant Pathology 14: 95-101.

Smith, H.G., 1986. Comparative studies of the sugar beet yellowing viruses: field incidence and effect on yield. Aspects of Applied Biology 13: 107-113.

Smith, H.G. \& J.A. Hinckes, 1987. Studies of the distribution of yellowing viruses in the sugar beet root crop from 1981 to 1984. Plant Pathology 36: 125-134.

Steudel, W., 1958. Versuche zur Übertragung des Vergilbungsvirus (Beta Virus 4) aul Zuckerrüben mit gestaffelter Individuenzahl des Übertragers Myzodes persicae. (Sulz.). Zucker 23: 538-542.

Thielemann, R. \& A. Nagi, 1977. Neuere Erfahrungen zum Vorkommen zweier Vergilbungsviren an Zuckerrüben in der Bundesrepublik Deutschland, zur Bedeutung der Vcktoren und der Ertragsverluste. Zeitschrift für Pflanzenkrankheiten und Pflanzenschutz 84: 257-269.

Thielemann, R. \& A. Nagi, 1979. Welche Bedeutung haben dic zur 'Aphis fabae-Gruppe' gehörenden Blattlausstämme für die Übertragung des schwachen Vergilbungsvirus auf BetaRüben? Zeitschrift für Pflanzenkrankheiten und Pflanzenschutz 86: 161-168.

Watson, M.A. \& M.J.R. Healy, 1953. The spread of beet yellows and beet mosaic viruses in the sugar-beet root crop II. The effect of aphid numbers on disease incidence. Annals of Applied Biology 40: 38-59.

Watson, M.A. \& G.D. Heathcote, 1966. The use of sticky traps and the relation of their catches of aphids to the spread of viruses in crops. Report Rothamsted Experimental Station for 1965, p. 292-300.

Watson, M.A. \& D.J. Watson, 1951. The effect of infection with beet yellows and beet mosaic viruses on the carbohydrate content of sugar-beet leaves, and on translocation. Annals of Applied Biology 38: 276-288.

Watson, M.A., R. Hull, J.W. Blencowe \& B.M.G. Hamlyn, 1951. The spread of beet yellows and beet mosaic viruses in the sugar-beet root crop. I. Field observations on the virus diseases of sugar-beet and their vectors Myzus persicae Sulz. and Aphis fabae Koch. Annals of Applied Biology 38: 743-764.

Werf, W. van der, F. Bonnier \& D. Peters, 1989a. Retrospective estimation of the date of infection with beet yellowing viruses in sugar-beet under field conditions. Netherlands Journal of Plant Pathology 95: in press.

Werf, W. van der, J. Guan, C. Kempenaar \& D. Peters, 1990. Transport, multiplication and latency period of beet yellowing viruses in sugar-beet under field conditions. Netherlands Journal of Plant Pathology 96: in press.

Wiesner, K., 1959. Ein Beitrag zur Epidemiologie der virösen Rübenvergilbung (Corium betae Holmes) in der Deutschen Democratischen Republiek. Wissenschaftliche Zeitschrift MartinLuther-Universität Halle-Wittenberg Math.-Nat. VIIl (4/5): 577-630.

Wit, C.T. de \& J. Goudriaan, 1978. Simulation of ecological processes. Centre for Agricultural Publishing and Documentation Pudoc, Wageningen, $175 \mathrm{pp}$.

Zadoks, J.C. \& R.D. Schein, 1979. Epidemiology and plant disease management. Oxford University Press, New York, 427 pp. 